\title{
Soil physicochemical properties and floristic composition of two ecosystems differing in plant diversity: fallows and meadows
}

\author{
Dominika Chmolowska • Maciej Kozak • \\ Ryszard Laskowski
}

Received: 9 July 2015 / Accepted: 28 December 2015 / Published online: 20 January 2016

(C) The Author(s) 2016. This article is published with open access at Springerlink.com

\begin{abstract}
Background and aims European farmland has been abandoned at an unprecedented rate over the last few decades, resulting in an increase of the area of fallows and a decrease in plant diversity in meadows. This work was aimed at determining whether differences in the persistence and plant diversity of the two ecosystem types, similar in plant biomass and geographical location, resulted in changes in soil physicochemical properties.

Methods Soil physicochemical properties and floristic composition were studied in six fallows at the initial stage of secondary succession and six fresh meadows with high plant diversity.
\end{abstract}

Responsible Editor: Jeffrey Walck

Electronic supplementary material The online version of this article (doi:10.1007/s11104-015-2788-7) contains supplementary material, which is available to authorized users.

D. Chmolowska $(\bowtie)$

Institute of Systematics and Evolution of Animals, Polish Academy of Sciences, Sławkowska 17, 31-016 Krakow, Poland e-mail: dominika.chmolowska@o2.p1

D. Chmolowska

e-mail: chmolowska@isez.pan.krakow.pl

M. Kozak

Institute of Botany, Jagiellonian University, Lubicz 46,

31-512 Krakow, Poland

R. Laskowski

Institute of Environmental Sciences, Jagiellonian University, Gronostajowa 7, 30-387 Krakow, Poland
Results Fallow soils had several-fold higher content of available phosphorus, potassium and nitrates. Meadow soils had a slightly higher $\mathrm{C}: \mathrm{N}$ ratio and water-holding capacity (WHC), what suggest more humus in meadow soil.

Conclusions The main differences in soil properties between meadows and fallows were after-effects of agricultural management, most probably previous fertilization. The difference in the $\mathrm{C}: \mathrm{N}$ ratio and $\mathrm{WHC}$ can be attributed to ecosystem ages. Abandoned farmlands had relatively good nutrient supply but low species diversity. Meadows, though depleted in available nutrients, showed high floristic richness. The legumes, which were more abundant in meadows, might have supplemented this ecosystem with the limiting $\mathrm{N}$.

Keywords Grassland · Abandoned farmland · Soil fertility Plant species richness $\cdot$ Secondary succession

\section{Introduction}

Recent decades have witnessed large changes in land use in Europe. During the transformation from communism to capitalism in Central and Eastern Europe, agricultural production became less profitable and much farmland was left without management. In Poland the area of fallows increased sixfold between 1990 and 2006 (Central Statistical Office 2001, 2007). In the Czech Republic the area of arable land also shrank, and permanent grassland increased by $13.8 \%$ between 1990 and 1999 (Bičík et al. 2001). In Lithuania the area 
of abandoned farmland more than doubled between 2003 and 2010 (Paśakarnis et al. 2013), and in different regions of the Russian Federation the area of plowed fields decreased by $10 \%$ on average for the whole nation (Smelansky 2003). In other European countries, farm fields are deserted due to natural constrains, soil erosion, socio-economic factors, demographic changes and institutional framework, as summarized by the FAO (Renwick et al. 2013). Various models predict more land abandonment in the next 20-30 years (Renwick et al. 2013). The predicted and ongoing abandonment of farmland affects mainly areas less suitable for farming: mountain areas (Alps, Apennines, Pyrenees, Harz Mountains, Elbe Sandstone mountains, Ore Mountains, and to a lesser extent the Carpathians), more northern latitudes (Sweden, Finland) and some other areas such as the Massif Central in France, the Thuringian Forest in Germany, the German/Czech border, and northwestern Iberia (Keenleyside and Tucker 2010).

The abandonment of arable fields has two sides. On the one hand, agronomists consider it to be a negative process in which overgrowth by weeds and the buildup of the weed seed bank, followed by bush succession, make it difficult to restore abandoned fields to agricultural production (Lauringson and Talgre 2003). On the other hand, it leads to various changes that are beneficial for ecosystem functioning and services. Several studies showed that an increasing number of plant species (Faliński 1986) provide habitats for a higher number of animal species (Van Buskirk and Willi 2004), turning the abandoned land into a diverse ecosystem. In many cases an improvement of soil properties is observed: for example, increased ammonium (Malicki and Podstawka-Chmielewska 1998), soil organic matter content (Billings 1941), soil organic carbon content and stability of soil aggregates (Erktan et al. 2015). Other benefits are reduced soil erosion, ceasing inorganic surpluses and lower greenhouse gas emissions (Renwick et al. 2013).

In the case of meadows, sustainable management over decades maintains species-rich communities. Such meadows are biodiversity reservoirs, sometimes hosting rare species (Plieninger et al. 2006). However, the expansion of fallows has been accompanied with a decrease in the total area of meadows in Poland (Central Statistical Office 2001, 2007). This is mainly due to cessation of traditional management of these seminatural communities, resulting in their degeneration and loss of plant diversity (e.g. Kornaś and Dubiel
1990; Zarzycki and Kaźmierczakowa 2006; Kozak 2007). The situation is similar in many other European countries (e.g. Burel and Baudry 1995; Losvik 1999; Mitlacher et al. 2002; Tasser and Tappeiner 2002; Pavlů et al. 2005). At the same time, meadows that are still in the agricultural system are subjected to more intensive management (Plantureux et al. 2005), resulting in a marked decline of biodiversity (Vickery et al. 2001; Niedrist et al. 2009; Allan et al. 2014). Loosing biodiversity can affect ecosystem services. There is a general agreement that maintaining ecosystem functioning within its normal operating range requires certain minimum number of species, and that in a changing environment higher number of species may be required (Botton et al. 2006). Ecosystem stability depends not only on species diversity but also on functional diversity (Botton et al. 2006), that is the diversity of processes taking place in and functions fulfilled by communities in a given environment. Numerous studies showed that greater plant diversity can lead to higher productivity in experimental fields (Hector et al. 1999; Cardinale et al. 2007) and in natural ecosystems (Flombaum and Sala 2008).

This study compared physicochemical soil properties of meadows and fallows - two ecosystem types similar in plant biomass and location but differing in their floristic composition and diversity. The fresh meadows in this research, representing communities of the Arrhenatherion alliance, are protected in the Natura 2000 network as a valuable endangered habitat, of a type which is rapidly disappearing in the European Union. Fallows were abandoned farmland in the initial stage of secondary succession. The study examined the soil nutrient status and we expected the fallows to be nutrient-depleted because they are no longer fertilized and the nutrients were removed from the soil with the last crop before abandonment. The study may be representative for areas undergoing similar land use changes, in particular in Central Europe.

\section{Methods}

Site description

The fallows and meadows studied in this research are located in the Beskid Sądecki Mountains (Polish Western Outer Carpathians) near the town of Krynica-Zdrój $\left(49^{\circ} 25^{\prime} 17^{\prime \prime} \mathrm{N}, 20^{\circ} 57^{\prime} 33^{\prime \prime} \mathrm{E}\right)$. Because the area is not suitable for crop farming, mainly due to its hilly 
landscape and mountain climate, pastures and extensively managed hay meadows have dominated agriculture in this area for centuries. Settled colonization of this area began in the early Middle Ages, and pastoralism, together with hay-making, was the dominant land use from the very beginning. It continued even after the Second World War despite the expulsion and resettlement of ethnic populations immediately after the war (Stawowczyk 2010). Nowadays the meadows are usually found on hills, and the crop fields are in places close to settlements and roads for easy access, often on flatter parts of the landscape.

The study plots were assigned to a type of ecosystem (fallow or meadow) according to floristic composition: a) presence of ruderal and segetal weeds (especially couch grass Elymus repens) in fallows; b) high proportion of species characteristic for the MolinioArrhenatheretea class (Ellenberg 1988) in meadows; and c) higher richness of the plant community in meadows $\left(>30\right.$ species per $\left.25 \mathrm{~m}^{2}\right)$ than in fallows $(<30$ species per $25 \mathrm{~m}^{2}$ ) (Table 1). The six fallows and six meadows were selected within a radius of a few kilometres (Fig. 1) and at similar elevations range (510-710 a.s.1. for fallows; 520-730 m a.s.1. for meadows; Table 1). Detailed information on the plant communities and spatial descriptors of the plots is given in Supplementary Material 1.

\section{Sampling}

The soil was sampled in October 2008 for physicochemical analyses and in June 2009 for N and root system biomass measurements. At each site, a total of ten soil cores were taken to $10 \mathrm{~cm}$ depth every $2 \mathrm{~m}$ along an $18 \mathrm{~m}$ long transect. The cores from each plot were pooled and sieved through $4 \mathrm{~mm}$ mesh. Moist field soil samples were stored at $4{ }^{\circ} \mathrm{C}$ prior to chemical analyses. Vegetation analyses were done in June 2009.

\section{Physicochemical analyses}

Dry weight was determined by drying $\sim 10 \mathrm{~g}$ moist field soil at $105{ }^{\circ} \mathrm{C}$ for ca. $12 \mathrm{~h}$. Maximum water holding capacity (WHC) was determined gravimetrically (Schlichting and Blume 1966) using 15-20 g moist field soil. Soil $\mathrm{pH}$ in $\mathrm{H}_{2} \mathrm{O}$ and in $1 \mathrm{M} \mathrm{KCl}$ was measured in soil extracts ( $5 \mathrm{~g}$ soil $\mathrm{dwt}$ : $25 \mathrm{ml}$ extractant) after agitation for $1 \mathrm{~h}$ and a settling period of $30 \mathrm{~min}$.

Soil organic matter (SOM) content was determined as loss on ignition after ca. $12 \mathrm{~h}$ combustion at $550{ }^{\circ} \mathrm{C}$.

Table 1 Elevation of study plots, root biomass, plant community species richness and Shannon-Wiener (S-W) diversity index; asterisks denote significant differences between fallows and meadows

\begin{tabular}{|c|c|c|c|c|}
\hline & $\begin{array}{l}\text { Altitude } \\
\mathrm{m}\end{array}$ & $\begin{array}{l}\text { Root biomass } \\
\mathrm{g} \mathrm{dm}^{-3}\end{array}$ & $\begin{array}{l}\text { Number of } \\
\text { plant species }\end{array}$ & $\mathrm{S}-\mathrm{W}$ diversity index \\
\hline \multicolumn{5}{|l|}{ Fallow } \\
\hline 1 & 710 & 17.4 & 22 & 2.26 \\
\hline 2 & 580 & 20.1 & 13 & 1.08 \\
\hline 3 & 500 & 15.1 & 23 & 1.96 \\
\hline 4 & 530 & 6.4 & 26 & 2.22 \\
\hline 5 & 510 & 12.8 & 19 & 1.56 \\
\hline 6 & 640 & 8.1 & 16 & 1.62 \\
\hline mean $\pm \mathrm{SD}$ & $578 \pm 83$ & $13.3 \pm 5.3$ & $20 \pm 5$ & $1.78 \pm 0.45$ \\
\hline \multicolumn{5}{|l|}{ Meadow } \\
\hline 1 & 725 & 7.2 & 42 & 3.38 \\
\hline 2 & 730 & 6.6 & 50 & 3.41 \\
\hline 3 & 720 & 10.2 & 41 & 3.45 \\
\hline 4 & 580 & 6.6 & 46 & 3.08 \\
\hline 5 & 520 & 10 & 47 & 3.13 \\
\hline 6 & 560 & 10.1 & 37 & 3.36 \\
\hline mean $\pm \mathrm{SD}$ & $622 \pm 96$ & $8.5 \pm 1.8$ & $44 \pm 5 * * *$ & $3.30 \pm 0.16 * *$ \\
\hline
\end{tabular}

$* P<0.05, * * P<0.01, * * * P<0.001$ 
Fig. 1 Spatial distribution of the study plots; $f$ and squares indicate fallows, $m$ and circles indicate meadows; numbers 1-6 following $f$ and $m$ indicate plot numbers in Supplementary Material 1 and 2

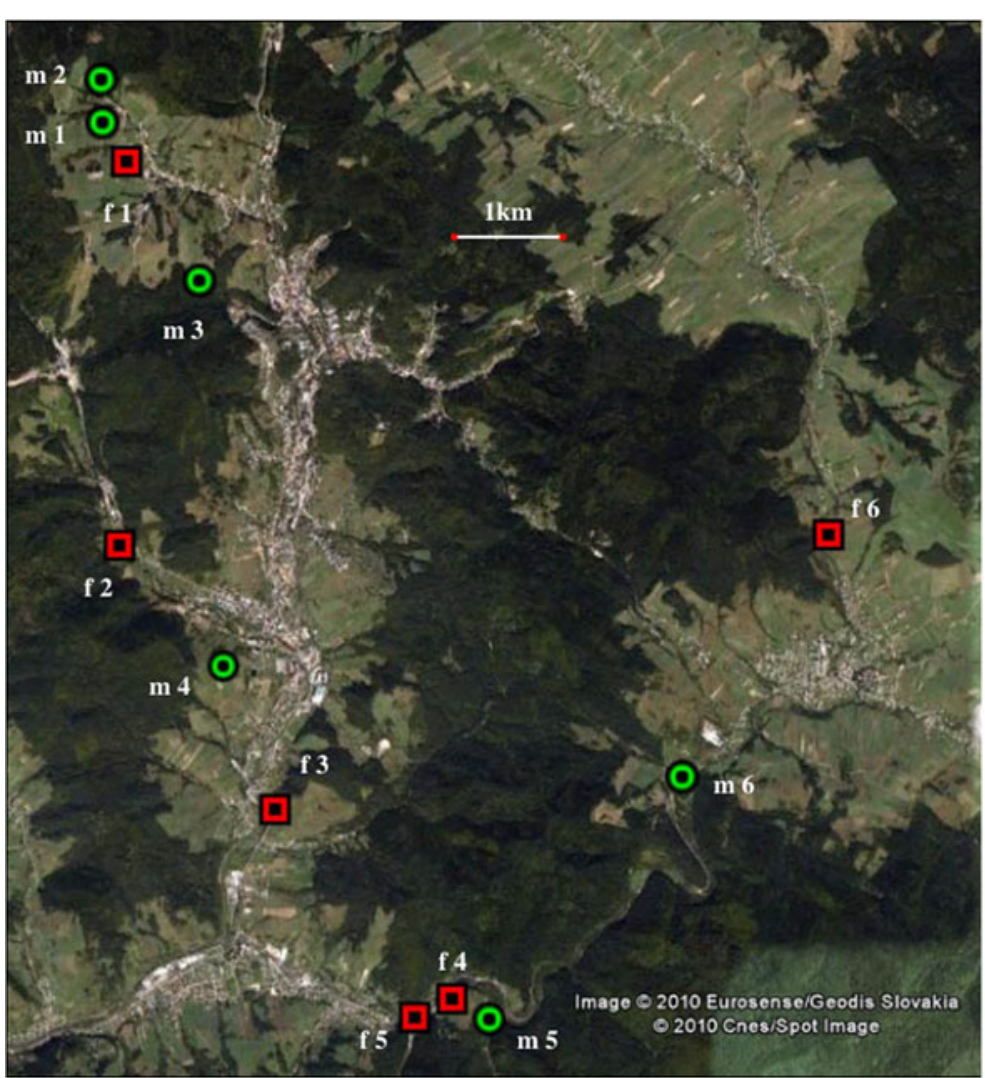

Soil dried at $105^{\circ} \mathrm{C}$ was used for measurements of total $\mathrm{C}, \mathrm{N}, \mathrm{Mn}, \mathrm{Ca}, \mathrm{K}$ and Na content, and cation exchange capacity (CEC). Total $\mathrm{C}$ and $\mathrm{N}$ content were measured using a $\mathrm{CHN}(\mathrm{O}) \mathrm{S}$ autoanalyser (Vario EL III, Elementar System $\mathrm{GmbH}$ ). Total Mn, Ca, K, Na content measurements were preceded by mineralization of $0.5 \mathrm{~g}$ dry soil in boiling nitric acid (V) (Suprapur, Merck). Total content of Mn was estimated by flame atomic absorption spectrometry (Perkin Elmer AAnalyst 800), and content of $\mathrm{Ca}, \mathrm{Na}$ and $\mathrm{K}$ by flame atomic emission spectrometry (Jenway, PFP 7). CEC was measured according to the protocol given by Hendershot and Duquette (1986) based on $\mathrm{BaCl}_{2}$ extraction. The presence of free calcium carbonate in soil was checked with $10 \% \mathrm{HCl}$ as described by Insam (1996). Available fractions of phosphorus and potassium were measured by the EgnerRiehm method following Karczewska and Kabała (2005). Content of $\mathrm{NO}_{3}{ }^{-}$and $\mathrm{NH}_{4}{ }^{+}$was measured with a continuous flow analyser (FIAcompact, MLE, Dresden, Germany) in $2 \mathrm{M} \mathrm{KCl}$ soil extracts (1:5 moist field soil mass:extractant, v:v). The soil particle size distribution was determined hydrometrically according to Sheldrick and Wang (1993) at the University of Science and Technology in Kraków, Poland, and soil type was designated according to the Polish Society of Soil Science Soil Classification (Polish Society of Soil Science 2009).

Plant community analysis

Phytosociological records were made by the standard method of Braun-Blanquet (1964) on a $25 \mathrm{~m}^{2}$ square in each study plot, scoring on the traditional seven-step cover-abundance scale. Nomenclature follows Mirek et al. (2002) for vascular plants and Ochyra et al. (2003) for mosses. Root and rhizome biomass was measured from underground plant parts wet-washed on a $0.2 \mathrm{~mm}$ sieve and air-dried.

Statistical analyses

The F test was used to verify the homogeneity of standard deviations in the two ecosystem types. If passed, fallows and meadows were compared with the test; otherwise the nonparametric median Mann-Whitney Utest was employed. A Pearson correlation matrix was 
constructed for soil physicochemical data. Parameters with absolute values of standardized skewness or standardized kurtosis $>2$ were $1 / y$-transformed. This had to be done for $\mathrm{C}: \mathrm{N}$ ratio, calcium content and CEC; 1/y transformation reverses the correlation coefficient sign.

The Shannon-Wiener diversity index was calculated for each plant community, using the Turboveg program (Hennekens and Schaminee 2001). For statistical analyses of plant composition data the cover-abundance scale was converted to a numeric scale according to Braun-Blanquet (1964) as described by Dzwonko (2007). For multidimensional analyses the environmental data were standardized. The Mantel test was run in the PAST program (Hammer et al. 2001) to see whether soil physicochemical properties and plant community composition were correlated with the spatial distribution of the sampling sites. We chose the Euclidean distance similarity measure and ran 5000 permutations in the analysis. Multidimensional scaling was performed in Canoco 4.51 (Biometris). Length of gradient was checked with detrended canonical analysis (DCA), as recommended by Leps and Smilauer (2003). Gradient length was 4.165 , so we chose a unimodal variant of gradient analysis. Because of the arch effect observed in the canonical analysis, DCA with detrending by segments was performed (Leps and Smilauer 2003). Canonical correspondence analysis (CCA) was performed to detect relationships between soil physicochemical properties, sample distribution and floristic composition. In both multidimensional analyses the data were not transformed and the option of down-weighting rare species was chosen. Monte Carlo tests with 1000 permutations were run, as suggested for $P=0.05$ (Kindt and Coe 2005), to detect which environmental factors significantly contributed to plant community structure.

\section{Results}

Plant communities

The fallows in this study are typical young fallows, most probably farm fields abandoned a few years ago. They are characterized by significant dominance of a few species, especially Elymus repens (fallows 2, 5, 6) and less frequently Holcus mollis (fallow 1), Ranunculus repens (fallow 4) or Armoracia rusticana and Poa trivialis (fallow 3) (Supplementary Material 1). Such high dominance of only one or two species drastically reduced the floristic diversity of these communities, in which only 19.8 species per $25 \mathrm{~m}^{2}$ were recorded and the average Shannon-Wiener index was 1.8 (Table 1). Plant species characteristic for the Arrhenatherion alliance, Arrhenatheretalia order and MolinioArrhenatheretea class occurred here much more seldom than in meadows. A distinctive feature of the fallows was the high share of ruderal plants and segetal weeds typical for the classes Agropyretea, Artemisietea and Stellarietea mediae (Supplementary Material 1).

The meadows were typical fresh meadows representing the Arrhenatherion alliance. In these species-rich communities we recorded 43.8 species per $25 \mathrm{~m}^{2}$ on average, and the mean Shannon-Wiener index was 3.3 (Table 1). Species richness $(\mathrm{t}=-9.035$, $P<0.0001)$ and diversity $(\mathrm{U}=36.0, P=0.005)$ differed significantly between fallows and meadows. The meadow biocenosis was formed mainly by numerous species characteristic for the Arrhenatheretalia order and Molinio-Arrhenatheretea class (Supplementary Material 1). Ruderal plants appeared here only sporadically and always in small numbers.

The $\mathrm{N}_{2}$-fixing symbiotic species noted within the two ecosystem types were: Trifolium repens, Trifolium pratense, Vicia cracca, Lathyrus pratensis, Vicia sepium and Lotus corniculatum. Apart from V. sepium, all of them were more abundant in meadows (Supplementary Material 1).

In DCA the two types of communities clustered separately (Fig. 2). The only exception was fallow 4, which was closer to the meadow cluster, mainly due to lower cover of Elymus repens as well as higher floristic diversity. The plant species most associated with fallows were: Elymus repens, Utrica dioica, Cirsium arvense, Chaerophyllum aromaticum, Armoracia rusticana and Holcus mollis (see also Supplementary Material 1). Plants typical for meadows were: Trifolium repens, Ranunculus acris, Rhinantus minor, Trisetum flavescens, Leontodon hispidus, Plantago lanceolata, and Arrhenatherum elatius. Among the meadows plot 4 was placed a little further from the others on the diagram.

The CCA showed similar results, with meadows and fallow 4 on one side of the graph and the other fallows on the opposite side (Fig. 3). The eigenvalue was 0.765 for the first axis and 0.490 for the second axis (Fig. 3). The gradient along Axis 1 was caused mostly by the content of available N, P and K in soil. The soil variables pointing towards meadows were high values of $\mathrm{C}: \mathrm{N}$ ratio, $\mathrm{pH}$ and $\mathrm{Ca}$ content, but those variables, especially 
Fig. 2 DCA ordination biplot (squares indicate fallows, circles indicate meadows). Axis 1 explains $23.5 \%$ and Axis 2 explains $10.0 \%$ of total variance. Letters in italics are the plant species with the largest input (weight above $15 \%$ ) to the model

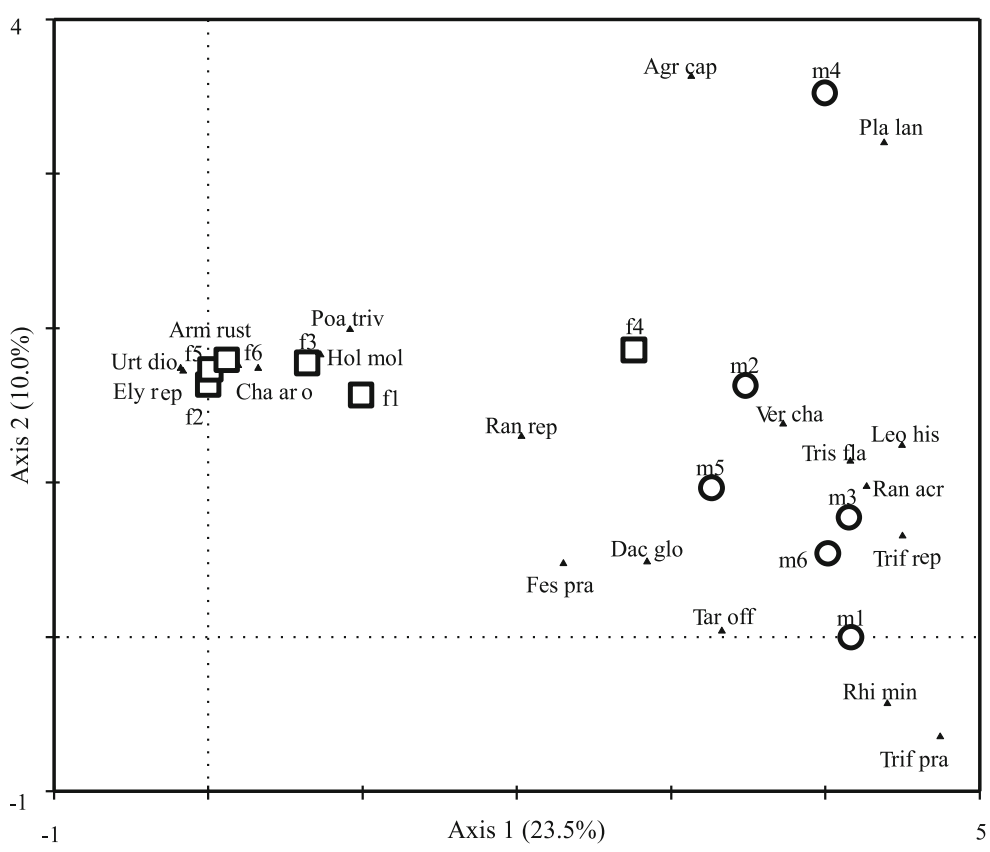

Ca content and $\mathrm{pH}$, were less important. Vicia cracca, Trifolium pratense, Ranunculus acris, Trisetum flavescens and Plantago lanceolata preferred soil with a higher $\mathrm{C}: \mathrm{N}$ ratio and lower nutrient content, and were typical for meadows. Lower $\mathrm{C}: \mathrm{N}$ ratio and higher nutrient content were connected with Elymus repens, Cirsium arvense, Chaerophyllum aromaticum, Fallopia convolvulus and Galium aparine, as suggested by the location of their marker points close to the vectors of available $\mathrm{N}, \mathrm{P}$ and $\mathrm{K}$ (Fig. 3). Of all the edaphic variables automatically selected by the model, only nitrate content was indicated by the permutation Monte Carlo test as statistically significant $(P=0.001, \mathrm{~F}=2.56)$.
Fig. 3 CCA ordination triplot. Scaling focused on inter-species distances, type of scaling: Hill's scaling, down-weighting of rare species (squares indicate fallows, circles indicate meadows). Axis 1 explains $32.9 \%$ and Axis 2 explains $21.0 \%$ of total variance. Letters in italics are the plant species with the largest input: above $40 \%$ fit to PC1 and PC2 (species with only one record were omitted). Arrows indicate six environmental variables selected by automatic forward selection, among which only nitrates were statistically significant according to the Monte Carlo test (1000 permutations: $\mathrm{NO}_{3}{ }^{-}$ $P=0.001, F=2.56$ )

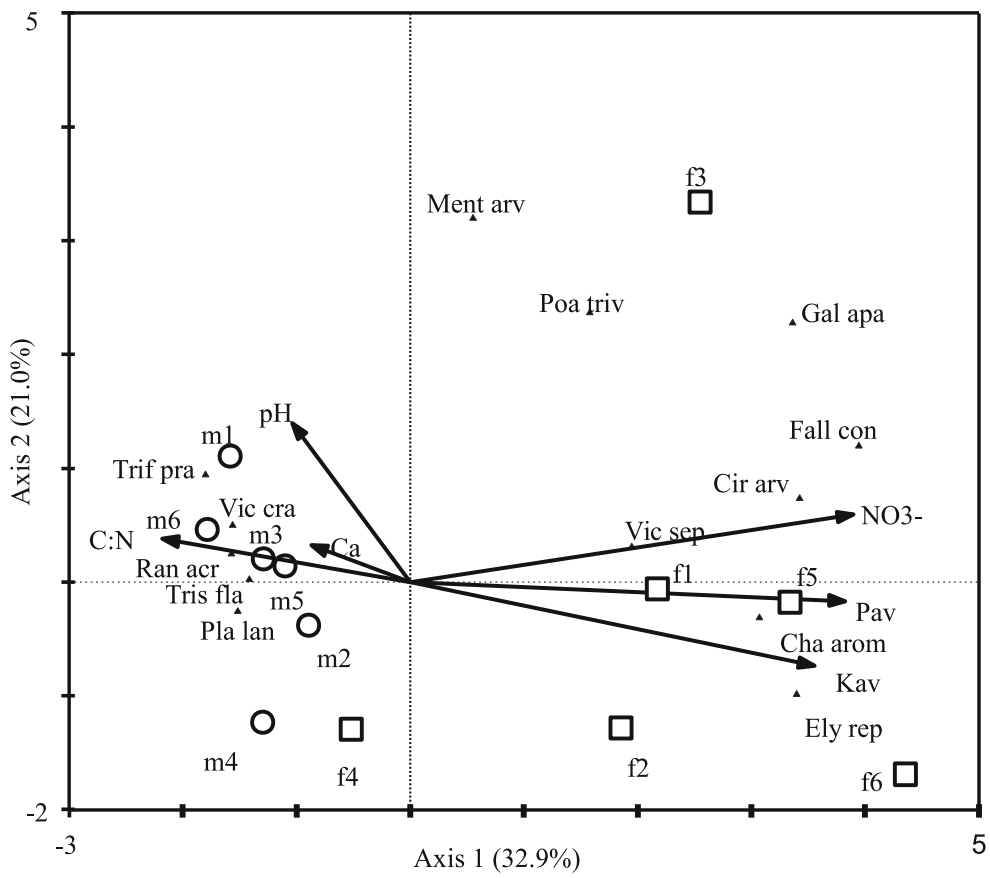


Root system weight did not differ between the two grassland types because of the dominance and masking effect of the coarse and heavy rhizomes of Elymus repens weed in the fallows (Table 1). During sieving it was clearly seen that the meadow root system was developed and densely packed but consisted of small, thin, lightweight underground plant parts, while in fallows it was dominated by few but heavy rhizomes of Elymus repens. There was no correlation between plant community composition and the spatial distribution of the study plots.

\section{Soil classification and chemistry}

The three recognized soil types were evenly represented in the two ecosystem types: each type had four soils of sandy loam, one loam and one silt loam (Supplementary Material 2). The $\mathrm{C}: \mathrm{N}$ ratio was significantly higher in meadows than in fallows $(\mathrm{U}=36, P=0.005)$. This difference can be associated with non-significant trend $(P=0.1)$ of meadow soils to have higher $\mathrm{C}$ content. Maximum WHC was also greater in meadows $(U=2$, $P=0.009)$. Compared with meadows, fallows have almost tenfold more available $\mathrm{P}(\mathrm{U}=0, P=0.005)$, and more than threefold higher available $\mathrm{K}(\mathrm{U}=4, P=0.03)$. Available $\mathrm{P}$ content was almost tenfold higher in fallows than in meadows, and available $\mathrm{K}$ content was more than threefold higher in fallows. Ammonium content was similar in the two ecosystems, and nitrate content in the fallows was about sevenfold higher than in the meadows ( $\mathrm{U}=0, P=0.005$ ) (Table 2).

Apart from WHC, C:N ratio and available $\mathrm{P}, \mathrm{K}$ and $\mathrm{NO}_{3}{ }^{-}-\mathrm{N}$, the soils were similar in other measured physicochemical parameters: content of sand, silt, clay and $\mathrm{SOM}$, total $\mathrm{N}, \mathrm{C}, \mathrm{Ca}, \mathrm{Na}$ and $\mathrm{Mn}$, cation exchange capacity (CEC) and $\mathrm{NH}_{4}{ }^{+}-\mathrm{N}$ (Table 2). The calcium carbonate was present in one soil: meadow 5 . The soil $\mathrm{pH}$ of fallows and meadows did not differ significantly, but the fallows were consistently acidic or slightly acidic, while the meadows ranged from acidic and slightly acidic to neutral and even alkaline in case of $\mathrm{pH}$ in $\mathrm{H}_{2} \mathrm{O}$ (Table 3). A number of soil properties were correlated (Table 4). The strongest relationships were between total $\mathrm{C}$ and $\mathrm{N}(r=0.97, P<0.0001)$, between $\mathrm{pH}$ in $\mathrm{H}_{2} \mathrm{O}$ and $\mathrm{pH}$ in $\mathrm{KCl}(r=0.95, P<0.0001)$, between $\mathrm{pH}$ in $\mathrm{H}_{2} \mathrm{O}$ and $\mathrm{Ca}(r=0.89, P=0.0002)$, and between $\mathrm{Ca}$ and $\mathrm{CEC}$ $(r=0.87, P=0.0002)$.

Table 2 Soil physicochemical properties of fallows and meadows: means, standard deviations and comparison of medians with MannWhitney U-test; n.s.: non-significant at $(P>0.05)$

\begin{tabular}{|c|c|c|c|c|}
\hline & & Fallow & Meadow & \\
\hline Soil properties & unit & mean $\pm \mathrm{SD}$ & mean $\pm \mathrm{SD}$ & fallow vs.meadow \\
\hline $\mathrm{pH}$ in $\mathrm{KCl}$ & & $4.9 \pm 0.4$ & $5.6 \pm 0.6$ & n.s \\
\hline $\mathrm{pH}$ in $\mathrm{H}_{2} \mathrm{O}$ & & $5.9 \pm 0.4$ & $6.7 \pm 1.2$ & n.s \\
\hline SOM & $\%$ & $4.4 \pm 0.6$ & $5.6 \pm 1.2$ & n.s \\
\hline Total N & $\%$ & $0.25 \pm 0.06$ & $0.29 \pm 0.06$ & n.s \\
\hline Total C & $\%$ & $2.56 \pm 0.59$ & $3.26 \pm 0.73$ & n.s \\
\hline $\mathrm{C}: \mathrm{N}$ & & $10.2 \pm 0.2$ & $11.1 \pm 0.6$ & $* *$ \\
\hline Total $\mathrm{Ca}$ & $\mathrm{mg} \mathrm{kg}^{-1}$ & $329 \pm 235$ & $2128 \pm 3953$ & n.s \\
\hline Total Na & $\mathrm{mg} \mathrm{kg}^{-1}$ & $62.9 \pm 14.0$ & $78.8 \pm 23.7$ & n.s \\
\hline Total Mn & $\mathrm{mg} \mathrm{kg}^{-1}$ & $662 \pm 268$ & $667 \pm 287$ & n.s \\
\hline CEC & $\operatorname{cmol}(+) \mathrm{kg}^{-1}$ & $1524 \pm 553$ & $2618 \pm 1665$ & n.s \\
\hline Available K & $\mathrm{mg} \mathrm{kg}^{-1}$ & $302 \pm 157$ & $83 \pm 30$ & $*$ \\
\hline Available P & $\mathrm{mg} \mathrm{kg}^{-1}$ & $41.8 \pm 25.9$ & $4.8 \pm 2.6$ & $* *$ \\
\hline $\mathrm{NO}_{3}^{-}$ & $\mathrm{mg} \mathrm{kg}^{-1}$ & $12.3 \pm 3.5$ & $1.7 \pm 2.4$ & $* *$ \\
\hline $\mathrm{NH}_{4}^{+}$ & $\mathrm{mg} \mathrm{kg}^{-1}$ & $3.3 \pm 1.4$ & $3.6 \pm 2.0$ & n.s \\
\hline Sand & $\%$ & $53.2 \pm 13.2$ & $54 \pm 9.5$ & n.s \\
\hline Fine & $\%$ & $38.5 \pm 10.3$ & $38.8 \pm 7.6$ & n.s \\
\hline Silt & $\%$ & $8.3 \pm 3.5$ & $7.2 \pm 2.3$ & n.s \\
\hline $\mathrm{WHC}_{\max }$ & $\mathrm{mg} \mathrm{g}^{-1}$ & $0.84 \pm 0.09$ & $1.16 \pm 0.23$ & $* *$ \\
\hline
\end{tabular}

$* P<0.05, * * P<0.01, * * * P<0.001$ 
Table 3 Soil $\mathrm{pH}$ in water and $1 \mathrm{M} \mathrm{KCl}$ of fallows and meadows and soil acidity classification. The soil $\mathrm{pH}$ classification is following Bednarek et al. (2004)

\begin{tabular}{|c|c|c|c|c|}
\hline & $\mathrm{pH}\left[\mathrm{H}_{2} \mathrm{O}\right]$ & classification & $\mathrm{pH}[\mathrm{KCl}]$ & classification \\
\hline \multicolumn{5}{|c|}{ fallow } \\
\hline 1 & 5.7 & $\mathrm{Ac}$ & 4.4 & VAc \\
\hline 2 & 5.6 & $\mathrm{Ac}$ & 4.4 & VAc \\
\hline 3 & 5.8 & $\mathrm{Ac}$ & 5.0 & Ac \\
\hline 4 & 5.5 & $\mathrm{Ac}$ & 4.4 & VAc \\
\hline 5 & 6.6 & SA & 5.6 & SA \\
\hline 6 & 6.5 & SA & 5.6 & SA \\
\hline \multicolumn{5}{|c|}{ meadow } \\
\hline 1 & 6.7 & SA & 5.2 & $\mathrm{Ac}$ \\
\hline 2 & 5.9 & $\mathrm{Ac}$ & 4.6 & Ac \\
\hline 3 & 6.9 & $\mathrm{Neu}$ & 5.4 & $\mathrm{Ac}$ \\
\hline 4 & 5.8 & $\mathrm{Ac}$ & 4.4 & VAc \\
\hline 5 & 7.7 & Alk & 7.4 & Alk \\
\hline 6 & 7.6 & Alk & 6.6 & $\mathrm{Neu}$ \\
\hline
\end{tabular}

$V A c$ very acidic, $A c$ acidic, $S A$ slightly acidic, Neu neutral, Alk alkaline

The Mantel test showed that soil physicochemical properties did not correlate with the spatial distribution of the sampling sites $(r=0.1, P=0.1)$. However, we noticed that all plots located along the same mountain watercourse (Muszynka river and its tributary, the Mochnaczka river), that is meadows 5 and 6 and fallows 5 and 6 , were noticeably less acidic than other respective ecosystem types. The other soils were located on hills or, in the case of fallow 2, in the valley of another mountain rivercourse (Czarny Potok creek).

\section{Discussion}

Secondary succession has been reported to increase SOM content (Billings 1941), organic C (Frouz et al. 2001; Erktan et al. 2015), Mg (Malicki and PodstawkaChmielewska 1998; Allison et al. 2007), $\mathrm{K}$ and N-NH${ }_{4}{ }^{+}$ (Malicki and Podstawka-Chmielewska 1998), soil pH and moisture (Allison et al. 2007). In present study, the $\mathrm{C}: \mathrm{N}$ ratio and maximum $\mathrm{WHC}$ were higher in meadows than in fallows. In a prairie $\mathrm{WHC}$ and $\mathrm{C}: \mathrm{N}$ ratio together with contents of SOM, C, N and S were higher in native and long-term restorations than in agricultural or more recently restored plots (McKinley et al. 2005). A higher $\mathrm{C}: \mathrm{N}$ ratio is typical of more developed ecosystems (e.g.
Table 4 Pearson correlations among soil physicochemical properties

\begin{tabular}{|c|c|}
\hline Correlated parameters & $\mathrm{r}$ \\
\hline SOM $[\%]$ and $\mathbf{N}[\%]$ & 0.84 \\
\hline SOM $[\%]$ and $\mathbf{N}[\%]$ & 0.8 \\
\hline SOM $[\%]$ and $\mathbf{N a ~}\left[\mathrm{mg} \mathrm{kg}^{-1}\right]$ & 0.75 \\
\hline SOM $[\%]$ and $\mathbf{M n}\left[\mathrm{mg} \mathrm{kg}^{-1}\right]$ & 0.63 \\
\hline $\mathbf{p H} \mathbf{H}_{[\mathbf{H 2 0}]}$ and $\left.\mathbf{p H} \mathbf{~} \mathrm{KCl}\right]$ & 0.95 \\
\hline $\mathbf{p H}_{[\mathbf{H 2 0}]}$ and $\mathbf{C : \mathbf { N } ^ { - 1 }}$ & -0.69 \\
\hline $\mathbf{p H}_{[\mathbf{H 2 0 ]}}$ and $\mathbf{C a}^{-\mathbf{1}}\left[\mathrm{mg} \mathrm{kg}^{-1}\right]$ & -0.89 \\
\hline $\mathbf{p H} \mathbf{H H 2 0 ]}$ and $\mathbf{C E C}^{-\mathbf{1}}\left[\mathrm{cmol}(+) \mathrm{kg}^{-1}\right]$ & -0.77 \\
\hline $\mathbf{p H} \mathbf{H}_{[\mathrm{KCl}]}$ and $\mathbf{C}: \mathbf{N}^{-\mathbf{1}}$ & -0.7 \\
\hline $\mathbf{p H} \mathbf{H K C l}$ and $\mathbf{C a}^{-\mathbf{1}}\left[\mathrm{mg} \mathrm{kg}^{-1}\right]$ & -0.83 \\
\hline $\mathbf{p} \mathbf{H}_{[\mathbf{K C l}]}$ and $\mathbf{C E C} \mathbf{C}^{-1}\left[\mathrm{cmol}^{\left.(+) \mathrm{kg}^{-1}\right]}\right.$ & -0.64 \\
\hline $\mathbf{p H} \mathbf{H C l}_{[\mathbf{K C}}$ and $\mathbf{N H}_{\mathbf{4}}^{+}\left[\mu \mathrm{g} \mathrm{g}^{-1}\right]$ & -0.59 \\
\hline $\mathbf{N}[\%]$ and $\mathbf{C}[\%]$ & 0.97 \\
\hline $\mathbf{N}[\%]$ and $\mathbf{N a}\left[\mathrm{mg} \mathrm{kg}^{-1}\right]$ & 0.77 \\
\hline $\mathbf{N}[\%]$ and $\mathbf{M n}\left[\mathrm{mg} \mathrm{kg}^{-1}\right]$ & 0.64 \\
\hline $\mathbf{N}[\%]$ and $\mathbf{C E C} \mathbf{C}^{-\mathbf{1}}\left[\mathrm{cmol}(+) \mathrm{kg}^{-1}\right]$ & -0.65 \\
\hline $\mathbf{C}[\%]$ and $\mathbf{N a}\left[\mathrm{mg} \mathrm{kg}^{-1}\right]$ & 0.79 \\
\hline $\mathbf{C}[\%]$ and $\mathbf{C E C}^{-1}\left[\mathrm{cmol}^{(+)} \mathrm{kg}^{-1}\right]$ & -0.68 \\
\hline $\mathbf{C a}^{-1}\left[\mathrm{mg} \mathrm{kg}^{-1}\right]$ and $\mathbf{C E C} \mathbf{C}^{-\mathbf{1}}\left[\mathrm{cmol}(+) \mathrm{kg}^{-1}\right]$ & 0.87 \\
\hline $\mathbf{N a}\left[\mathrm{mg} \mathrm{kg}^{-1}\right]$ and $\mathbf{M n}\left[\mathrm{mg} \mathrm{kg}^{-1}\right]$ & 0.58 \\
\hline $\mathbf{N a}\left[\mathrm{mg} \mathrm{kg}^{-1}\right]$ and $\mathbf{C E C} \mathbf{C}^{-\mathbf{1}}\left[\mathrm{cmol}(+) \mathrm{kg}^{-1}\right]$ & -0.65 \\
\hline $\mathbf{M n}\left[\mathrm{mg} \mathrm{kg}^{-1}\right]$ and $\mathbf{C E C} \mathbf{C}^{-1}\left[\mathrm{cmol}(+) \mathrm{kg}^{-1}\right]$ & -0.64 \\
\hline $\mathbf{K}_{\mathbf{2}} \mathbf{O}^{-1}\left[\mathrm{mg} \mathrm{kg}^{-1}\right]$ and $\mathbf{P}_{\mathbf{2}} \mathbf{O}_{\mathbf{5}}\left[\mathrm{mg} \mathrm{kg}^{-1}\right]$ & -0.68 \\
\hline $\mathbf{K}_{\mathbf{2}} \mathbf{O}^{-1}\left[\mathrm{mg} \mathrm{kg}^{-1}\right]$ and $\mathbf{N O}_{3}^{-}\left[\mu \mathrm{g} \mathrm{g}^{-1}\right]$ & -0.71 \\
\hline $\mathbf{P}_{\mathbf{2}} \mathbf{O}_{\mathbf{5}}\left[\mathrm{mg} \mathrm{kg}^{-1}\right]$ and $\mathbf{N O}_{\mathbf{3}}^{-}\left[\mu \mathrm{g} \mathrm{g}^{-1}\right]$ & 0.78 \\
\hline
\end{tabular}

Only correlations significant at $P<0.05$ are shown; correlation coefficients with $|r|>0.8$ are bolded

Blaško et al. 2015) because during humus formation the available organic nitrogen compounds are exhausted and only the recalcitrant fractions remain (Berg and Laskowski 2006). Humus has beneficial effects on soil physicochemical properties including enhanced water retention (Peña-Méndez et al. 2005). The higher C:N and WHC of meadow soils suggest higher humus content in meadows and can be associated with the longer persistence of this ecosystems as compared to the fallows.

The clear differences in the content of available K, $\mathrm{P}$ and $\mathrm{NO}_{3}-\mathrm{N}$, which were much higher in fallows than in meadows, were most likely due to remnants of fertilizers used in the fields before they were left fallow. The increased phosphate content found in some South American fallows was also judged to be a long-lasting 
effect of past fertilization (Abadín et al. 2002). In excess of $\mathrm{N}$ availability, regardless of whether inorganic or organics are applied, nitrogen in fertilizer in oxic conditions ends up mainly as nitrates. This may explain the higher content of nitrates in fallows. Usage of ammoniacontaining fertilizers, could have led to the acidity of exarable fields. Different N partitioning in ecosystems depending on $\mathrm{N}$ availability was described by Schimel and Bennet (2004). At the medium level of $\mathrm{N}$ availability, there would be an $\mathrm{NH}_{4}{ }^{+}$-dominated $\mathrm{N}$ economy in the ecosystem and the soil content of $\mathrm{NO}_{3}{ }^{-}$would be low. Such a scenario likely takes place in some grasslands (Schimel and Bennet 2004) and would refer to meadows. At very high relative $\mathrm{N}$ availability, which may occur in agricultural systems, the system becomes $\mathrm{NO}_{3}{ }^{-}$dominated (Schimel and Bennet 2004). The fallows with higher $\mathrm{N}$-accessibility would be a nitrate dominated system. The discrepancy between the total nitrogen content and its availability in the fallows and meadows points out differences in SOM quality.

Because the total $\mathrm{N}$ content is similar in the two ecosystem types studied, probably at long term there was no great difference in the amount of $\mathrm{N}$ left in soil between agricultural fields and meadows. It was observed in many other mountain ranges within Polish Carpathians that farmers usually put slurry or mineral fertilizers on arable fields, and manure on meadows. Even if agricultural plots were fertilized more than meadows, we might not observe differences in the content of the total $\mathrm{N}$ on ex-arable fields in comparison to meadows. Other studies show increasing soil total $\mathrm{N}$ along secondary succession from agriculture to native grassland (e.g. McKinley et al. 2005), which may prove fertilizer remains on fallows as well as point out on increasing $\mathrm{N}$ content during plant succession. The meadows, on the other hand, were additionally supplemented with $\mathrm{N}$ due to symbiotic $\mathrm{N}_{2}$ fixation. There is abundant evidence that $\mathrm{N}$ fixation can facilitate the input of significant amounts of this element to ecosystems (Knops et al. 2002). The legumes took a major part in the meadow plant communities composition while in fallows they were subordinate. Acidic soils, which were more frequent within fallows, disfavor the growth of many legume species and Nfixing symbionts (Bordeleau and Prévost 1994). The relationship between legumes and soil $\mathrm{pH}$ is not straightforward. The most acidic meadow 4 had indeed the lowest contribution of Fabaceae, though the alkaline meadow 5 was the second.
To see whether the studied fallows were more nutrient-depleted than agricultural soils in Poland, we compared the soil fertility of the studied fallows and meadows against a country-wide survey of 216 agricultural soils (Siebielec et al. 2012). On the whole, the fallows appeared to have retained good fertility. These findings are against the presumption of fallows, the abandoned agricultural fields, to be nutrient exploited. In other Central and Eastern European countries less fertile land that produces lower yields was often left aside (Bičík et al. 2001; Smelansky 2003; Prishchepov et al. 2013). In contrary, another report from Poland showed that soil of high quality for agriculture was also abandoned (Niedźwiecki et al. 1998). All the fallow and meadow soils in this study fell within the highest SOM content class under Polish standards for agricultural soil quality (over $3.5 \%$ ). The averaged total $\mathrm{N}$ content in the studied fallows and meadows $(0.3 \%)$ was higher compared to Polish agricultural soils $(0.1 \%)$. Considerably high contents of SOM and total $\mathrm{N}$ were reported earlier for this part of Poland, and were attributed to a better hydrological regime (Siebielec et al. 2012). The available P content of the fallows was low, falling in the lower quartile of the reference agricultural soils. Available $\mathrm{P}$ in the meadow soils was below the minimal values measured in farm fields (Siebielec et al. 2012). The measured available $\mathrm{K}$ content of the fallows soil was high, generally above the mean and median of the Polish farmland soils (Siebielec et al. 2012). The meadow soils had very low $\mathrm{K}_{2} \mathrm{O}$ content, near the lowest quartile of the agricultural soils. The low content of $\mathrm{K}$ in meadow soils suggests that the parent soil material in the area is not rich in this element and that meadows were not or little fertilized with K. Apart from that the soil load of this element largely depends on soil CEC, which in turn depends on silt and humus content and soil pH (Siebielec et al. 2012). Because the fallows and meadows had similar silt content and CEC, the high content of available $\mathrm{K}$ in the fallows suggests that the soils of the studied area have high sorption capacity and that the overload of potassium in fertilizer was not leached even after abandonment of the fields. The dependence of CEC on certain soil properties was also supported by the increase of CEC with total C, N and soil $\mathrm{pH}$. Even if the total Ca concentrations in studied fallows fell within the ranges measured in Poland, the high acidity of these soils suggests that liming would be needed in case of returned agricultural use. 
We examined the relationships between habitat, soil $\mathrm{pH}$ and calcium content. The especially high $\mathrm{pH}$ of the soils from meadows 5 and 6 can be explained by their high calcium content. The positive correlation between soil $\mathrm{pH}$ and calcium is well documented (e.g. Dick et al. 2000; Grayston et al. 2004). The contribution of Ca and other ions ( $\mathrm{Mg}, \mathrm{K}, \mathrm{Na}, \mathrm{Al}, \mathrm{Fe}, \mathrm{Mn})$ in the $\mathrm{pH}$ of studied soils is displayed by strong positive correlation between $\mathrm{CEC}, \mathrm{Ca}$ content and soil $\mathrm{pH}$. The alkaline soil in meadow 5 contained free $\mathrm{CaCO}_{3}$, which presumably originates from the bedrock. In general the parent material in this part of Carpathians are Miocene conglomerates, sandstones and shales (Oszczypko 2004). All these rock types may contain incrustations of different materials, including $\mathrm{CaCO}_{3}$, which occasionally can increase $\mathrm{Ca}$ content in topsoil. In addition, slightly lower soil acidity of meadows 5 and 6 and fallows 5 and 6 can be reasoned by the presence of the river muds. The muds of dynamic rivers (mud type II) have higher soil $\mathrm{pH}$, around 7.1-7.8 (Myślińska 2001). In particular, along the Muszynka river, where are meadows 5 and 6 and fallow 5 , there are many mineral water bores rich in $\mathrm{Ca}^{2+}$ and $\mathrm{Mg}^{2+}$ due to the presence of $\mathrm{Ca} / \mathrm{Mg}$ veins in rocks. It is possible that its watercourse contains more calcium in its springs or bedrock than the Czarny Potok creek (fallow 2). However, as we did not aim at comparing mountain river valleys, we do not have real replicates of such soils. In the meadow 5 , with alkaline soil, a smaller share of species characteristic for the Arrhenatherion alliance was noticed (Supplementary Material 1). This cannot be solely explained by the higher $\mathrm{pH}$ of the soil, because all these plants can grow on soils with a wide $\mathrm{pH}$ range. This soil was also an upper outlier in $\mathrm{C}: \mathrm{N}$ ratio and nitrate content in regard to the other meadows. The differences in plant composition can be explained by a little different habitat properties together with biotic factors, e.g. available seed bank.

The ordination analysis did not cluster plots exactly in the same way as the botanical analysis of plant communities. The multidimensional ordination, as a completely objective method, treats all species as equal and, in result, loses some more sophisticated but important information. For example, it does not take into account the information regarding occurrence of plant species, which differ in ranges of their ecological tolerance. Moreover, the presence of a species in a single plot automatically affects the ordination result regardless of its habitat preferences. For this reason meadow 5, with slightly smaller share of species characteristic for Arrhenatherion alliance, was close to other meadows on the DCA and CCA diagrams, while meadow 4 was distanced. Meadow 4 is separated from the other meadows on the diagram due to the significantly higher cover of Alchemilla crinita, Agrostis capillaris, Geum rivale and Rhytidiadelphus squarrosus, as well as lower share or absence of species recorded in the most part of meadows: Achillea millefolium, Heracleum sphondylium, Trifolium pratense, T. repens, Crepis biennis, Taraxacum officinale, Dactylis glomerata, Ranunculus repens and Festuca pratensis. The multidimensional analysis does not test significance of differences, what is offered by other tests, such as multivariate ANOVA (MANOVA). It is more a method to visualize the relationships between the samples in a convenient graphical way.

Both studied ecosystem types are dominated by species typical for rich (eutrophic) soils (Zarzycki et al. 2002), but plants associated with extremely fertile habitats, such as Urtica dioica, Chaerophyllum aromaticum and Rumex obtusifolius, occur almost exclusively on fallows. Most species numerously present on fallows usually reproduce also in a vegetative way. They quickly spread and in just few years can absolutely dominate particular patches, limiting the growth of less expansive species. Ruderal and segetal weeds are well adapted to strongly disturbed habitats such as arable lands, but most of them do not tolerate regular and long-term mowing. However there are also some common meadow species, e.g. Poa trivialis, Ranunculus repens, Agrostis capillaris, which also can quickly spread on young fallows. The floristic composition of such sites is a bit more similar to meadows, but they still differ markedly in plant diversity. Such situation occurs in fallow 4 dominated by Ranunculus repens, accompanied by some ruderal and segetal weeds (Supplementary Material 1).

The fallow 4, which differed markedly from other fallows according to DCA and CCA, most probably represents somewhat older successional stage as suggested by its higher floristic diversity, lower Elymus repens cover and slightly higher share of meadow species. This fallow plot was placed on a slope and was farther from settlements than the other fallows, the circumstances which may have hastened abandonment of this plot. In the Italian Alps, pastures on steeper slopes are abandoned more often (Cocca et al. 2012). The lower available $\mathrm{P}, \mathrm{K}$ and $\mathrm{NO}_{3}{ }^{-} \mathrm{-}$ content of fallow 4 
than in the other fallows may have resulted from longer abandonment, and the steepness of the slope may have accelerated leaching of nutrients; together or alone, each of those factors would favour the changes in the plant community.

Increasing root number with increasing dominance of grasses in prairie secondary succession is a phenomenon described already in early studies such one by Judd and Weldon 1939 (Billings 1941). In our study, the root systems clearly differed in their structure: the meadows consisted of numerous, densely packed thin roots and rhizomes, branched, which were difficult to tear apart, while roots and rhizomes in the fallows were coarse, in low density, and loose. The roots system structure reflected the biocenosis development and successional advance, saturation and plant competition being low at the initial stages of the succession and high in ecosystems rich in plant species such these mountain meadows. The lower plant competition at the initial stages of the succession in old fields than at equilibrium on prairie, followed by lower niche overlap, were suggested by Parrish and Bazzaz (1976). With increasing number of species, niches of the subordinate species become narrower, what can facilitate their coexistence with dominant species (von Felten et al. 2009). In our study higher plant diversity, especially abundance of species with important ecological functions such as symbiotic acquisition of biogens was a foundation for ecosystem successful functioning. The presence of legumes and herbs had highly positive effects on ecosystem productivity, with T.pratense in particular (Hector et al. 1999). While the bean plants more abundant on meadows might have supplemented meadows with $\mathrm{N}$, mycorrhiza symbiosis can provide plants also with other limiting nutrients, in particular P. In both the fallows and the meadows, most plant species reported in the literature are arbuscular mycorrhizal symbionts (Wang and Qiu 2006), which suggests the same plant species potential for the symbiosis in the two ecosystems. However, regardless plant community composition, plant symbiosis with AMF is promoted in habitats limited by resources, especially P (Smith and Read 2008), and such were the meadows.

\section{Conclusions}

The soils under the two grassland types showed a few differences and many similarities in physicochemical properties. The soil $\mathrm{C}: \mathrm{N}$ ratio and maximum water retention was slightly higher in the older, speciesricher meadows than in fallows. Available $\mathrm{P}, \mathrm{K}$ and $\mathrm{NO}_{3}{ }^{-}-\mathrm{N}$ contents were significantly higher in fallows then in meadows, presumably resulting from past human management. Other soil physicochemical properties measured did not differ between ecosystem types and, thus successional stages. We noted local specificity of soil $\mathrm{pH}$ regardless the small distance between the plots and a positive correlation between soil $\mathrm{pH}$ and calcium content.

The fallows still had good potential for plant production; their contents of SOM, total nitrogen and available potassium were as high or higher than in reference farmland soils in Poland. Farms in the studied area are fragmented, small, and family-owned. Therefore, rather than to poor soil, the abandonment of agricultural fields in this area is likely due to socio-economic reasons.

The mountain fresh meadows of high floristic richness and diversity maintained the ecosystem services owing to symbiotic interactions in addition to human sustainable management. The meadows were less frequently acidic than fallows, and with the presumed higher content of humus this provides a better habitat for plants, soil micro- and macrobiota.

Acknowledgments This research was performed at the Jagiellonian University in Kraków, Poland (grant No. DS 758). The first author's $\mathrm{PhD}$ thesis included material from this work. Special thanks go to the Forest Research Station in Krynica-Zdrój, Agricultural University in Krakow, Poland, for a kind cooperation and help with searching for the study plots. We thank Dominik Płoskonka for soil types designation.

Open Access This article is distributed under the terms of the Creative Commons Attribution 4.0 International License (http:// creativecommons.org/licenses/by/4.0/), which permits unrestricted use, distribution, and reproduction in any medium, provided you give appropriate credit to the original author(s) and the source, provide a link to the Creative Commons license, and indicate if changes were made.

\section{References}

Abadín J, Gonzalez-Prieto SJ, Sarmiento L, Villar MC, Carballas $\mathrm{T}$ (2002) Successional dynamics of soil characteristics in a long fallow agricultural system of the high tropical Andes. Soil Biol Biochem 34:1739-1748

Allan E, Bossdorf O, Dormann CF, Prati D, Gossner MM, Tscharntke $\mathrm{T}$ (2014) Interannual variation in land-use 
intensity enhances grassland multidiversity. PNAS 111(1): 308-313

Allison VJ, Yermakov Z, Miller RM, Jastrow JD, Matamala R (2007) Using landscape and depth gradients to decouple the impact of correlated environmental variables on soil microbial community composition. Soil Biol Biochem 39(2):505516

Bednarek R, Dziadowiec H, Pokojska U, Prusinkiewicz Z (2004) Badania ekologiczno - gleboznawcze. PWN, Warsaw, p 200

Berg B, Laskowski R (2006) Changes in substrate composition and rate-regulating factors during decomposition. Adv Ecol Res 38:102-156

Bičík I, Jeleček L, Štěpánek V (2001) Land-use changes and their social driving forces in Czechia in the 19th and 20th centuries. Land Use Policy 18:65-73

Billings WD (1941) Quantitative correlations between vegetational changes and soil development. Ecology 22(4):448-456

Blaško R, Holm Bach L, Yarwood SA, Trumbore SE, Högberg P, Högberg MN (2015) Shifts in soil microbial community structure, nitrogen cycling and the concomitant declining $\mathrm{N}$ availability in ageing primary boreal forest ecosystems. Soil Biol Biochem 91:200-211

Bordeleau LM, Prévost D (1994) Nodulation and nitrogen fixation in extreme environments. Plant Soil 161:115-125

Botton S, van Heusden M, Parsons JR, Smidt H, van Straalen N (2006) Resilience of microbial systems towards disturbances. Crit Rev Microbiol 32:101-112

Braun-Blanquet J (1964) Pflanzensoziologie. Grundzüge der Vegetationskunde. Springer, Wien-New York

Burel F, Baudry J (1995) Species biodiversity in changing agricultural landscapes: a case study in the Pays d'Auge, France. Agric Ecosyst Environ 55:193-200

Cardinale BJ, Wright JP, Cadotte MW et al (2007) Impacts of plant diversity on biomass production increase through time because of species complementarity. Proc Natl Acad Sci U S A 104:18123-18128

Central Statistical Office (2001) Statistical yearbook of agriculture. Statistical Publishing Establishment, Warsaw

Central Statistical Office (2007) Statistical yearbook of agriculture. Statistical Publishing Establishment, Warsaw

Cocca G, Sturaro E, Gallo L, Ramanzin M (2012) Is the abandonment of traditional livestock farming systems the main driver of mountain landscape change in Alpine areas? Land Use Policy 29(4):878-886

Dick WA, Cheng L, Wang P (2000) Soil acid and alkaline phosphatase activity as $\mathrm{pH}$ adjustment indicators. Soil Biol Biochem 32:1915-1919

Dzwonko Z (2007) Przewodnik do badań fitosocjologicznych. Sorus, Poznań-Kraków

Ellenberg H (1988) Vegetation ecology of Central Europe. Cambridge University Press, Cambridge

Erktan A, Cécillon L, Graf F, Roumet C, Legout C, Rey F (2015) Increase in soil aggregate stability along a Mediterranean successional gradient in severely eroded gully bed ecosystems: combined effects of soil, root traits and plant community characteristics. Plant Soil. doi:10.1007/s11104-015-2647-6

Faliński JB (1986) Sukcesja roślinności na nieużytkach porolnych jako przejaw ekosystemu wyzwolonego spod długotrwałej presji antropogenicznej (Vegetation succession on abandonend farmland as a dynamics manifestation of ecosystem liberal of long continuance anthropopression. Part I.). Wiadomości Botaniczne (Botanical News) 30(1): $25-50$

Flombaum P, Sala OE (2008) From the cover: higher effect of plant species diversity on productivity in natural than artificial ecosystems. Proc Natl Acad Sci U S A 105:6087-6090

Frouz J, Keplin B, Lukes A, Materna J, Du C, Chalupsky J (2001) Soil biota and upper soil layer development in two contrasting post-mining chronosequences. Ecol Eng 17:275-284

Grayston S, Campbell C, Bardgett R, Mawdsley J, Clegg C, Ritz K, Millard P (2004) Assessing shifts in microbial community structure across a range of grasslands of differing management intensity using CLPP, PLFA and community DNA techniques. Appl Soil Ecol 25(1):63-84

Hammer O, Harper DAT, Ryan PD (2001) PAST: paleontological statistics software package for education and data analysis. Paleontol Electron 4(1)

Hector A, Schmid B, Beierkuhnlein C, Caldeira MC, Diemer M, Dimitrakopoulos PG, Finn JA et al (1999) Plant diversity and productivity experiments in European grasslands. Science 286:1123-1127

Hendershot WH, Duquette M (1986) A simple barium chloride method for determining cation exchange capacity and exchangeable cations. Soil Sci Soc Am J 50:605-608

Hennekens SM, Schaminee JHJ (2001) Turboveg, a comprehensive database management system for vegetation data. J Veg Sci 12:589-591

Insam H (1996) Organic carbon by dry combustion. In: Schinner F, Öhlinger R, Kandeler E, Margesin R (eds) Methods in soil biology. Springer - Verlag, Berlin Heidelberg, pp 400-402

Karczewska A, Kabała C (2005) Metodyka analiz laboratoryjnych gleb i roślin. Uniwersytet Przyrodniczy we Wrocławiu, Instytut Gleboznawstwa i Ochrony Środowiska Rolniczego, Zakład Ochrony Środowiska (Wrocław University of Environmental and Life Sciences, Institute of Soil Sciences and Environmental Protection)

Keenleyside C, Tucker G (2010) Farmland abandonment in the EU: an assessment of trends and prospects. London: WWF and IEEP (November 93)

Kindt R, Coe R (2005) Tree diversity analysis. A manual and software for common statistical methods for ecological and biodiversity studies. World Agroforestry Centre, Nairobi

Knops JMH, Bradley KL, Wedin DA (2002) Mechanisms of plant species impacts on ecosystem nitrogen cycling. Ecol Lett 5: 454-466

Kornaś J, Dubiel E (1990) Przemiany zbiorowisk łąkowych w Ojcowskim Parku Narodowym w ostatnim trzydziestoleciu. Prądnik, Prace Muz Szafera 2:97-106

Kozak M (2007) Zróżnicowanie zbiorowisk łąkowych w Gorcach (Polskie Karpaty Zachodnie). Botanical papers 41

Lauringson E, Talgre L (2003) Problems of abandoned fields. Agron Res 1:63-67

Leps J, Smilauer P (2003) Multivariate analysis of ecological data using CANOCO. Cambridge University Press

Losvik M (1999) Plant species diversity in an old, traditionally managed hay meadow compared to abandoned hay meadows in southwest Norway. Nord J Bot 19:473-487

Malicki L, Podstawka-Chmielewska E (1998) Zmiany fitocenozy i niektórych właściwości gleby zachodzące podczas odłogowania oraz będące efektem zagospodarowania 
wieloletniego odłogu. Bibl Frag Agron 5:97-114 (in Polish with English summary)

McKinley VL, Peacock AD, White DC (2005) Microbial community PLFA and PHB responses to ecosystem restoration in tallgrass prairie soils. Soil Biol Biochem 37(10):1946-1958

Mirek Z, Piękoś-Mirek H, Zając A, Zając M (2002) Flowering plants and pteridophytes of Poland a checklist. Institute of Botany, Polish Academy of Sciences, Kraków

Mitlacher K, Poschlod P, Rosén E, Bakker JP (2002) Restoration of wooded meadows - a comparative analysis along a chronosequence on Öland (Sweden). Appl Veg Sci 5:63-73

Myślińska E (2001) Grunty organiczne i laboratoryjne metody ich badania. PWN, Warsaw, pp 157-170

Niedrist G, Tasser E, Luth C, Dalla Via J, Tappeiner U (2009) Plant diversity declines with recent land use changes in European Alps. Plant Ecol 202(2):195-210

Niedźwiecki E, Meller E, Malinowski R (1998) Wartość i przydatność rolnicza odłogowanych gleb Pomorza zachodniego. Bibl Frag Agron 5:35-43 (in Polish with English summary)

Ochyra R, Żarnowiec J, Bednarek-Ochyra H (2003) Census catalogue of Polish mosses. Institute of Botany, Polish Academy of Sciences, Kraków

Oszczypko N (2004) The structural position and tectonosedimentary evolution of the Polish Outer Carpathians. Prz Geol 52:780791

Parrish JAD, Bazzaz FA (1976) Underground niche separation in succesional plants. Ecology 57:1281-1288

Paśakarnis G, Morley D, Maliene V (2013) Rural development and challenges establishing sustainable land use in Eastern European countries. Land Use Policy 30:703-710

Pavlů V, Hejcman M, Pavlů L, Gaisler J, Nežerková P, Guerovich Andaluz M (2005) Vegetation changes after cessation of grazing management in the Jizerské Mountains (Czech Republic). Ann Bot Fenn 42:343-349

Peña-Méndez ME, Havel J, Patočka J (2005) Humic substances compounds of still unknown structure: applications in agriculture, industry, environment, and biomedicine. J Appl Biomed 3:13-24

Plantureux S, Peeters A, McCracken D (2005) Biodiversity in intensive grasslands: effect of management, improvement and challenges. Agron Res 3(2):153-164

Plieninger T, Höchtl F, Spek T (2006) Traditional land-use and nature conservation in European rural landscapes. Environ Sci Pol 9:317-321

Polish Society of Soil Science (2009) Klasyfikacja Uziarnienia Gleb i Utworów Mineralnych. Soil Sci Annu 60(2):5-16

Prishchepov AV, Müller D, Dubinin M, Baumann M, Radeloff VC (2013) Determinants of agricultural land abandonment in
post-Soviet European Russia. Land Use Policy 30(1):873884

Renwick A, Jansson T, Verburg PH, Revoredo-Giha C, Britz W, Gocht A, McCracken D (2013) Policy reform and agricultural land abandonment in the EU. Land Use Policy 30(1):446457

Schimel JP, Bennet J (2004) Nitrogen mineralization: challenges of a changing paradigm. Ecology 85(3):591-602

Schlichting E, Blume HO (1966) Bodenkundliches Praktikum. Paul Parey, Hamburg

Sheldrick BH, Wang C (1993) Particle size distribution. In: Carter MR (ed) Soil sampling and methods of analysis. Lewis Publishers, Boca Raton, pp 499-511

Siebielec G, Smreczak B, Klimkowicz-Pawlas A, MaliszewskaKordybach B, Terelak H, Koza P, Suszek B (2012) Monitoring chemizmu gleb ornych w Polsce w latach 2010-2012. Instytut Uprawy, Nawożenia i Gleboznawstwa, Puławy

Smelansky IE (2003) Biodiversity of agricultural lands in Russia: current state and trends. IUCN - The World Conservaton Union, Moscow, $52 \mathrm{pp}$

Smith SE, Read DJ (2008) Mycorrhizal Symbiosis, 3rd edn. Academic Press, Elsevier

Stawowczyk K (2010) Geobotaniczne aspekty i flora pasma Radziejowej w Beskidzie Sądeckim. Doctoral dissertation. Jagiellonian University in Kraków

Tasser E, Tappeiner U (2002) Impact of land use change on mountain vegetation. Appl Veg Sci 5:173-184

Van Buskirk J, Willi Y (2004) Enhancement of farmland biodiversity within set-aside land. Conserv Biol 18:987-994

Vickery JA, Tallowin JR, Feber RE, Asteraki EJ, Atkinson PW, Fuller RJ, Brown VK (2001) The management of lowland neutral grasslands in Britain: effects of agricultural practices on birds and their food resources. J Appl Ecol 38:647-664

Von Felten S, Hector A, Buchmann N, Niklaus PA, Schmid B, Scherer-Lorenzen M (2009) Belowground nitrogen partitioning in experimental grassland plant communities of varying species richness. Ecology 90:1389-1399

Wang B, Qiu Y-L (2006) Phylogenetic distribution and evolution of mycorrhizas in land plants. Mycorrhiza 16(5):299-363

Zarzycki J, Kaźmierczakowa R (2006) Changes in fresh meadows and pastures in the Pieniny National Park during the last 35 years of the 20th century. Stud Naturae 54(Part I):275-304, in Polish with English summary

Zarzycki K, Trzcińska-Tacik H, Różański W, Szelag Z, Wołek J, Korzeniak U (2002) Ecological indicator values of vascular plants of Poland. Biodivers Pol 2:1-183 